\title{
ERC1/RET Fusion Protein
}

National Cancer Institute

\section{Source}

National Cancer Institute. ERC1/RET Fusion Protein. NCI Thesaurus. Code C99722.

A fusion protein encoded by the ERC1/RET fusion gene. This protein is comprised of the $\mathrm{N}$-terminal half of the ELKS/Rab6-interacting/CAST family member 1 protein, including the coiled-coil domain, fused with most of the C-terminal cytoplasmic domain of the proto-oncogene tyrosine-protein kinase receptor Ret protein, including the tyrosine kinase domain. 